Biol. Neonate 1973;23:I-IV

\title{
Contents, Vol. 23, 1973
}

\section{Contents}

Paton, J. B.; Fisher, D. E.; Saba, T. M., and Behrman, R. E.: Measurement of

Liver Blood Flow in the Infant Monkey. A Comparison of Methods ... 1

Krauer, B.; Rosegger, H.; Salloch, R., and Scopes, J.: Pretreatment of Pregnant

Rabbits with Chlorpromazine. Assessment of any Enzyme-Inducing Effect

on the Fetus 8

Novak, M.; Hahn, P.; Penn, D.; Monkus, E., and Skala, J.: The Role of Carnitine in Subcutaneous White Adipose Tissue from Newborn Infants 11

Novak, M.; Hahn, P.; Penn, D.; Monkus, E., and Kirby, L.: Metabolism of Sub-cutaneaous

Adipose Tissue in the Immediate Postnatal Period of Human Newborns. Developmental Changes in Some Cytoplasmic Enzymes .... 19

Williams, M. L.: Lipid Peroxidation in Fetal Rat Liver Mitochondria 25

Stolc, V.; Knopf, J., and Stolcova, E.: Iodine Concentration and Content in the

Organs of Rat during Postnatal Development 35

Rubecz, I. and Mestyán, J.: Energy Metabolism and Intravenous Nutrition of Premature Infants.

I. The Responses of Oxygen Consumption, Respiratory Quotient and Substrate Utilization to Infusion of Aminosol-Glucose .... 45

Bakke, J. L.; Lawrence, N. L., and Bennett, J.: Late Effects of Perinatal Morphine Administration on Pituitary-Thyroidal and Gonadal Function

Paul, K.; Dittrichová, J., and Pavlíková, E.: The Course of Quiet Sleep in Infants 78

Kaufman, N. and Wyllie, J. C.: The Absorption of 59Fe by the Rat Fetus 90

Adlard, B. P. F.; Dobbing, J., and Smart, J. L.: An Alternative Animal Model

for the Full-Term Small-for-Dates Human Baby 95

Basu, T. K.; Dickerson, J.W.T., and Parke, D.V.: Effect of Underfeeding Suck

ling Rats on the Activity of Hepatic Drug Metabolizing Enzymes 109

Fouron, J.-C.: Dynamic of the Placental Transfer of Digoxin in the Dog 116

Bursaux, E.; Freminet, A.; Brossard, Y., and Poyart, C. F.: Exchange Trans

fusion in the Neonate with ACD or CPD Stored Blood 123

Symonds, E. M. and Furler, I.: Plasma Renin Levels in the Normal and Anephric

Fetus at Birth 133

Soltész, Gy.; Joyce, J., and Young, M.: Protein Synthesis Rate in the Newborn

Lamb 139

Gale, T. F. and Ferm, V. H.: Skeletal Malformations Resulting from Cadmium

Treatment in the Hamster 149

Zgorzalewicz, B.: Activity of sRNA Amino Acyl Synthetases in Ontogenic Devel opment of Rabbit Brain 161

Schuit, K. E. and Dickie, M. W.: Induction of Enzyme Activity during Fetal Devel opment. The Appearance of Ornithine Transcarbamylase Activity in Rat

Liver 171 
Kurz, D. L.; Eyring, E. J., and Roach, J. E.: Serum Zinc in the Newborn

Contents

III

Alexander, D. P.; Britton, H.G.; Nixon, D.A.†; Ratcliffe, J.G., and Red

stone, D.: Corticotrophin and Cortisol Concentrations in the Plasma of

the Chronically Catheterised Sheep Fetus 184

Walsh, S. Z. and Gyulai, F.: The Effect of Cry on Heart Rate and the Q-A2 Inter

val in Early and Late Clamped Infants 193

Pribylová, H.; Kimlová, I., and §troufová, A.: The Effect of Intravenous Fruc

tose and Glucose on Metabolism and Plasma Insulin Levels in Newborn

Infants 205

McKay, E. and Thom, H.: Immunoglobulins in Haemolytic Disease of the Newborn 214

Hems, D. A.: Palpable Regular Jerking Movements of the Human Fetus: A Possible

Respiratory Sign of Fetal Distress 223

Laga, E. M.; Driscoll, S. G., and Munro, H. N.: Quantitative Studies of Human

Placenta. I. Morphometry 231

Laga, E. M.; Driscoll, S.G., and Munro, H. N.: Quantitative Studies of Human

Placenta. II. Biochemical Characteristics 260

Calverley, J. and Redstone, D.: Acute Effects and Long-Term Neurological

Consequences of Insulin-Induced Hypoglycaemia in the Newborn Rabbit 285

Pushpendran, C. K. and Eapen, J.: Studies on Lipids of Brain, Kidneys and Liver of Mice during Postnatal Development 303

Brachet, E. A.: Presence of the Complete Sorbitol Pathway in the Human Normal Umbilical Cord Tissue $\quad 314$

Heringová, A. and Jirsov $\Lambda$, V.: The Influence of Phenobarbitone on Bilirubin Clearance $\quad 325$

Fosbrooke, A. S. and Wharton, B.A.: Plasma Lipids in Umbilical Cord Blood from Infants of Normal and Low Birth Weight 330

Stolc, V.; Knopp, J., and Stolcova, E.: Effect of Varying Iodine Intake on its

Concentration in Rat Tissues during Early Development 339

Nicholson Scott, J. and Traurig, H. H.: Radioactivity in Reproductive Organs

and the Liver of Neonatal and Adult Rats Following 3H-Testosterone

Administration $\quad 346$

Blackmore, D.: Effect of Early Postnatal Starvation on Subsequent Thyroid

Function $\quad 359$

Adebonojo, F. O.: Synthesis and Storage of Lipids by Cultured Adipocytes of a

Human Neonate. Effects of Sera from Obese and Nonobese Human

Adults 366

Yeary, R.A.; Gerken, D., and Davis, D. R.: Postnatal Development of Hepatic

Drug-Metabolizing Enzymes in the Gunn Rat

Krasner, J.; Juchau, M. R., and Yaffe, S. J.: Postnatal Developmental Changes

in Hepatic Biliburin UDP-Glucuronyl Transferase. Studies on the

Solubilized Enzyme 381

Alexander, D. P.; Assan, R.; Britton, H.G., and Nixon, D.A.: Impermeability

of the Sheep Placenta to Glucagon 391

Ward, C.J. and Walker, D.G.: Regulation of Enzyme Development for Glycerol 
Utilization by Neonatal Rat Liver 403

Stanescu, R.; Stanescu, V., and Maroteaux, P.: Histological and Histochemical

Studies on the Human Growth Cartilage in Fetuses and Newborns 414

IV

Contents

Stanescu, V.; Stanescu, R., and Maroteaux, P.: Chemical Studies on the Human

Growth Cartilage in Fetuses and Newborns 432

Vallet-Strouve, C. and Tordet-Caridroit, C.: Desaturation on Linoleic Acid

in the Liver and Brain during the Development of Rats with Intra-

Uterine Growth Retardation 446

Bass, N. H. and Lundborg, P.: Respiratory Depressant Effects of Morphine on

the Central Nervous System of the Infant Rat 456

Varia 324

Author Index 469

Subject Index 470

S. Karger · Basel · München $\mathbf{\text { Paris }} \cdot$ London · New York · Sydney Arnold-Böcklin-Strasse 25, CH-4011 Basel (Switzerland)

All rights, included that of translation into other languages, reserved.

Photomechanic reproduction (photocopy, microcopy) of this volume or parts thereof without special permission of the publishers is prohibited.

(C) Copyright 1973 by S. Karger AG, Verlag für Medizin und Naturwissenschaften, Basel Printed in Switzerland by Buchdruckerei Fritz Pochon-Jent AG, Bern 